\title{
First evidence of hybridization between endangered sterlets (Acipenser ruthenus) and exotic Siberian sturgeons (Acipenser baerii) in the Danube River
}

\author{
Arne Ludwig · Sebastian Lippold · Lutz Debus • \\ Ralf Reinartz
}

Received: 28 February 2008/ Accepted: 15 May 2008/Published online: 3 June 2008

(C) Springer Science+Business Media B.V. 2008

\begin{abstract}
Most natural populations of Eurasian sturgeons have declined dramatically during recent decades, reaching historic low levels today. During the same period, sturgeon has become very popular in European aquaculture. Because many hatcheries are located near rivers, their unintentional escape is often documented, especially during floods. Until now, no cases of successful hybridization of these escaped fish with wild stocks have been reported. In this study, the genetic structure of a highly threatened population of sterlets (Acipenser ruthenus) from the Upper Danube was analysed as a requirement for their conservation. Surprisingly, we observed genotypes and morphotypes of Siberian sturgeon (Acipenser baerii), as well as hybrids between this species and native sterlets. This hybridization poses a serious threat for the
\end{abstract}

A. Ludwig $(\bowtie) \cdot$ S. Lippold

Department for Evolutionary Genetics, Leibniz Institute for Zoo and Wildlife Research, 10252 Berlin, Germany e-mail: ludwig@izw-berlin.de

\section{S. Lippold}

Department of Evolutionary Genetics, Max-PlanckInstitute for Evolutionary Anthropology,

Deutscher Platz 6, 04103 Leipzig, Germany

L. Debus

NAWA GbR, Am Dorfteich 7, 18184 Broderstorf/EMF GmbH, Forstweg 3, 31582 Nienburg, Germany

R. Reinartz

Büro für Fischereifragen und Gewässerökologie, Schöppingenweg 70, 48149 Munster, Germany survival of this isolated sterlet population in the upper part of the Danube. For the first time, natural reproduction is documented for Siberian sturgeon outside their natural range in Europe. This finding demonstrates the risk of extinction by hybridisation of endangered populations. We would like to stress that taking into consideration the risks for native sturgeon populations, farmed sturgeon should not be released into the wild, and all measures should be taken to prevent their accidental escape.

Keywords Introgression - Release program . Extinction by hybridisation

\section{Introduction}

Today sturgeons and paddlefishes (Acipenseridae) are highly endangered freshwater fishes. Overharvesting and habitat destruction have caused dramatic population declines worldwide. Due to the successful management of North American species, their situation is less critical than that of their Eurasian counterparts (Pikitch et al. 2005). Several serious risks jeopardize all Eurasian species and populations; the most important are unsustainable harvest and poaching, river damming, and the intentional or unintentional release or escape of exotic sturgeon species into natural waters. Several efforts have been made to reduce the impact of these threats; e.g. the development of genetic approaches for trade control 
(Ludwig 2008) and the building of fish passes and lifts in many rivers (Pavlov 1989). Also, to boost the sturgeon fishery, many populations have been stabilized over the past few decades by hatchery and release programs.

These stocking efforts have resulted in an overload of homogenous, sometimes non-native, genotypes which are responsible for inbreeding and outbreeding depressions (Ludwig 2006). Although inbreeding is less critical in fishes due to the huge number of offspring, outbreeding is a major risk especially for threatened populations/species with a limited range and only small effective population sizes. The admixture of non-native alleles to local genepools results in the dilution and/or an irreparable loss of locally adopted alleles or allelic combinations. This effect is especially evident for threatened populations because they are by definition of small size and can be overthrown by large numbers of introduced specimens. This negative impact of outbreeding is exacerbated by inter-species hybridisations. Despite these hybrids being less fertile', their existence have been documented for sturgeon a few times. Hybrids are often characterized by a greater growth performance; replacing native species, and often causing their extinction.

Simulations have demonstrated that hybridisation is the most rapidly acting genetic threat to endangered populations, with extinction often occurring in less than five generations (Wolf et al. 2001). Hughes et al. (2003) showed that a resident genotype of freshwater shrimp was extinct after translocation of slightly different genotypes. Sometimes hybrids result from intended release programs (Becker et al. 2007), and in other cases from habitat alterations (Freyhof et al. 2005) or from unintended escapes of hatchery fish (Birstein et al. 1998). However, natural sturgeon hybrids are often rare (Ludwig et al. 2002). Most times, backcrosses with native specimens resulted in a "genetic cleaning" of nuclear genotypes, so that evidence for ancestral hybridisation is often only detectable in mitochondrial DNA (Ludwig et al. 2003; Birstein et al. 2005).

Members of the family Acipenseridae display a strong tendency for inter-species hybridization under altered environmental conditions as well as through artificial propagation. In aquaculture, hybrids between different species are sometimes considered superior to the parental species. Aquaculture of sturgeons has undergone dynamic development worldwide, and Siberian sturgeon (Acipenser baeri) has become the preferred species in European aquaculture (Bronzi et al. 1999). Siberian sturgeons originally inhabiting Asian (Siberian) rivers from the Kolyma in the east to the $\mathrm{Ob}$ in the west are easy to handle, fast growing, and reproduce quickly under hatchery conditions. The escape of farmed Siberian sturgeons is often reported, especially during flooding events (Maury-Brachet et al. 2008) which have become increasingly frequent in Europe during the last few decades. Nevertheless, until now natural reproduction outside of their native range has not been documented.

Here we describe the first case of natural reproduction of non-native Siberian sturgeons in Western Europe, and furthermore their hybridization with native sterlets (A. ruthenus), in the Upper Danube River. This hybridization poses a serious threat for the survival of this isolated sterlet population in the upper part of the Danube.

\section{Material and methods}

Fourteen acipenserid fishes were caught in the stretch of the Danube River beneath the Jochenstein Weir near the border between Germany and Austria (rkm 2203.31; Fig. 1). Additionally, 19 reference samples of Siberian sturgeon (Lake Baikal $=13$; Lena River $=2$; Aquaculture $=4$ ) were used for comparison together with previously published sequences of Acipenser baeri (AF168469, AF168480-3, AF1684878, AF168476-7, AF168493-4, AF168497). Sequences of Acipenser ruthenus were compared with reference samples from the rivers Danube and Volga (population genetics data will be published elsewhere).

Meristics

Originally the specimens were collected during the course of a conservation program for the population genetic screening of Danube sterlets as a prerequisite for their artificial propagation and release. This Upper Danube population is threatened by extinction and isolated from the next populations downstream in Slovakia by many weirs (Reinartz 2002). Most of the fish were released back into the river after small fin clips were taken, however seven specimens were retained for the collection of morphological data, and 


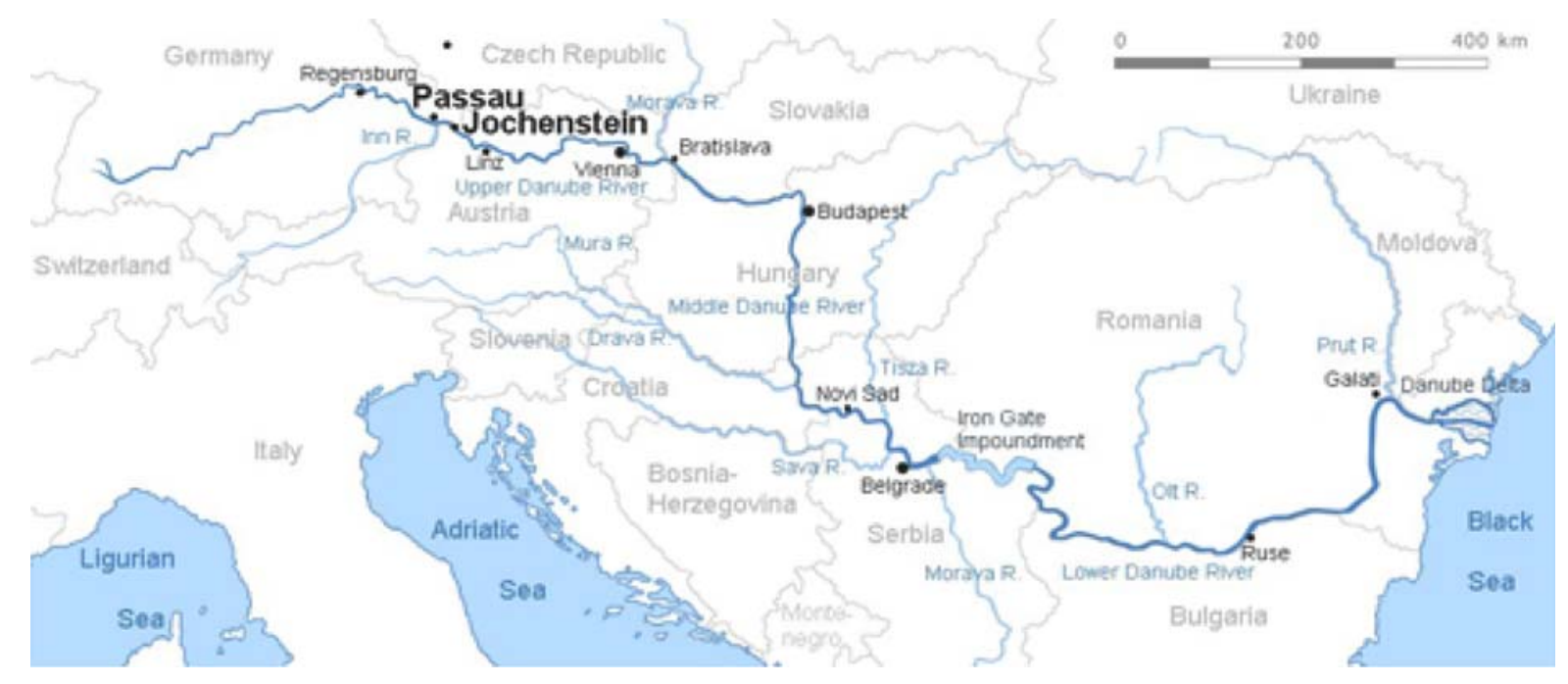

Fig. 1 Map of the Danube River showing sample location near Weir Jochenstein, Austria. Map used for Fig. 1 was modified after D. Ullrich and used under license CC-by-sa / http://de.wikipedia.org/wiki/Donau

were then transferred to ponds as potential broodstock for artificial propagation.

The species identifications were conducted based on previously published meristic and morphological data from Acipenserids (Debus 1995). Although this database does not include specific meristic data from Danube River sterlets, it contains meristic data of all described sturgeon and paddlefish species from many populations, including several populations of Volga River sterlets and Siberian sturgeons of different origins.

\section{Genetics}

DNA was extracted from tissue samples using DNeasy ${ }^{\circledR}$ tissue kit (QIAGEN). The following primers F.for (5'-GCA TCT GGT TCC TAT TTC AGG TCC$3^{\prime}$ )-F.rev (5'-TAT TAG GCT TGT TTC GGC GTA AGG- $3^{\prime}$ ) were used for amplification of partial mitochondrial D-loop sequences. PCR was carried out in a total volume of $25 \mu$ l containing; $1 \mathrm{U}$ Taq DNA polymerase, $10 \mathrm{pmol}$ of each primer, approx. $10 \mathrm{ng}$ DNA, $100 \mu \mathrm{M}$ of each dNTP, $2.5 \mathrm{~mm} \mathrm{MgCl}_{2}$ and $2.5 \mu \mathrm{L} 10 \times$ incubation buffer, under the following reaction conditions: one cycle at $94^{\circ} \mathrm{C}$ for $5 \mathrm{~min}$, followed by 30 cycles at $94^{\circ} \mathrm{C}$ for $30 \mathrm{~s}, 56^{\circ} \mathrm{C}$ for $30 \mathrm{~s}, 72^{\circ} \mathrm{C}$ for $30 \mathrm{~s}$, and a final extension of at least $3 \mathrm{~min}$ at $72^{\circ} \mathrm{C}$. PCR products were purified using QIAquick ${ }^{\circledR}$ PCR Purification Kit (QIAGEN). Cycle sequencing was performed following the standard procedure. Sequences were visualized using an automated sequencer (ABI 3110).

Allele lengths and distribution were determined for nine microsatellites: Afu19, Afu34, Afu39, Afu68 (May et al. 1997); Spl101, Spl105; Spl173 (McQuown et al. 2000); Aox23, Aox45 (King et al. 2001). PCR was performed in a total volume of $25 \mu \mathrm{l}$, containing $1 \mathrm{U}$ Taq DNA polymerase, 10 pmol of each primer, about 10-50 ng DNA, $100 \mu \mathrm{M}$ of each $\mathrm{dNTP}, 2.5 \mathrm{~mm} \mathrm{MgCl}_{2}$ and $2.5 \mu \mathrm{l} 10 \times$ incubation buffer. Amplifications were performed under the following reaction profile: one cycle at $94^{\circ} \mathrm{C}$ for $3 \mathrm{~min}, 30$ cycles at $94^{\circ} \mathrm{C}$ for $30 \mathrm{~s}$, the locus-specific annealing temperature for $30 \mathrm{~s}, 72^{\circ} \mathrm{C}$ for $30 \mathrm{~s}$; and a final extension at $72^{\circ} \mathrm{C}$ for $10 \mathrm{~min}$. Fragment size was determined on an ABI 3110 automatic sequencer, using the Genescan 2.0 and an internal size standard (GeneScan-250 LIZ, Applied Biosystems).

\section{Results}

Meristics

Five specimens exhibited meristic and morphological characteristics which were to variable extents consistent with Siberian sturgeon (A. baerii) as described in the database (Table 1). For three of these specimens, pre-anal scute counts were inconsistent with that expected for the true A. baerii. One specimen 
Table 1 Identification of species or hybrids based on morphology and genetic studies

\begin{tabular}{llll}
\hline Sample & mtDNA & Ploidy (no of alleles) & Morphology \\
\hline A-Joch-01 & A. ruthenus & $2 n$ (A. ruthenus) & - \\
A-Joch-02 & A. ruthenus & $2 n$ (A. ruthenus) & - \\
A-Joch-03 & A. ruthenus & $2 n$ (A. ruthenus) & - \\
A-Joch-04 & A. ruthenus & $3 n$ (hybrid) & A. baerii \\
A-Joch-05 & A. ruthenus & $2 n$ (A. ruthenus) & - \\
A-Joch-06 & A. ruthenus & $3 n$ (hybrid) & - \\
A-Joch-07 & A. ruthenus & $3 n$ (hybrid) & - \\
A-Joch-08 & A. ruthenus & $3 n$ (hybrid) & A. baerii \\
A-Joch-09 & A. ruthenus & $2 n$ (A. ruthenus) & - \\
A-Joch-10 & A. ruthenus & $2 n$ (A. ruthenus) & A. ruthenus \\
A-Joch-11 & A. baerii & $4 n$ (A. baerii) & A. baerii \\
A-Joch-12 & A. ruthenus & $3 n$ (hybrid) & A. baerii \\
A-Joch-13 & A. ruthenus & $3 n$ (hybrid) & A. baerii \\
A-Joch-14 & A. ruthenus & $2 n$ (A. ruthenus) & A. ruthenus \\
\hline
\end{tabular}

showed similarities to the stellate sturgeon ( $A$. stellatus) for some meristic characters, but shared most diagnostic characters with A. baerii (e.g. skin without sterlet scuteles and very short snout in contrast to stellate sturgeon which is characterized by a very long snout). Two specimens were identified as sterlets (A. ruthenus) based on their meristics.

\section{Genetics}

Thirteen (of 14) specimens shared sterlet (A. ruthenus) mitochondrial haplotypes (EU185053-5)
(Table 1). One specimen had a Siberian sturgeon (A. baerii) haplotype (EU185052). The two species are separated by 49 interspecific substitutions (18.77\% sequence divergence (Fig. 2). Additionally, both species differ in their number of chromosomes and their ploidy level (Birstein et al. 1993; Ludwig et al. 2001). Siberian sturgeons have 248 chromosomes, whereas sterlets have 118 chromosomes (reviewed in Birstein et al. 1993). Therefore differences of individual allelic number/locus can be used to determine the species. Eight specimens showed $\geq 3$ alleles in one or more loci indicating hybrids or pure Siberian sturgeons. Moreover, allele lengths differ between both species for the following loci: Aox23, Afu39, Afu68, Afu34, Afu19 and Spl101 (data available on request). Five specimens showed alleles diagnostic for $A$. baerii samples $(n=22)$ on the one hand, and on the other hand they shared sterlet-like mtDNA haplotypes (Table 1; Fig. 3). It is likely that these five individuals are hybrids.

\section{Discussion}

The sterlet was once the most widespread sturgeon species in the Danube River with populations occurring from the Danube Delta near the Black Sea up to city of Ulm (rkm 2586) as well as in numerous tributaries in historic times (Reinartz 2002). The current conservation status of sterlets in the Danube varies depending on the conservation and environmental measures applicable in each country's

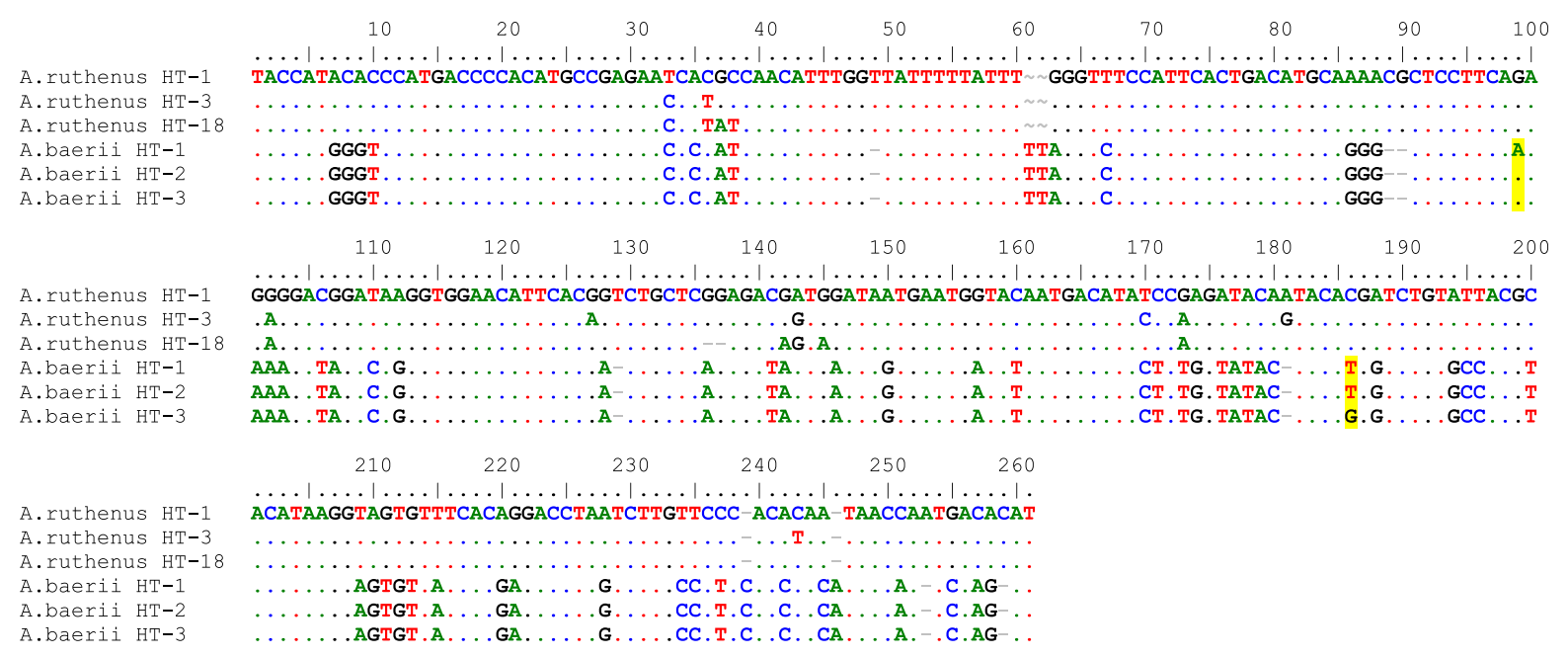

Fig. 2 Alignment of $\mathrm{mt}$ d-loop haplotypes indicating diagnostic substitutions 


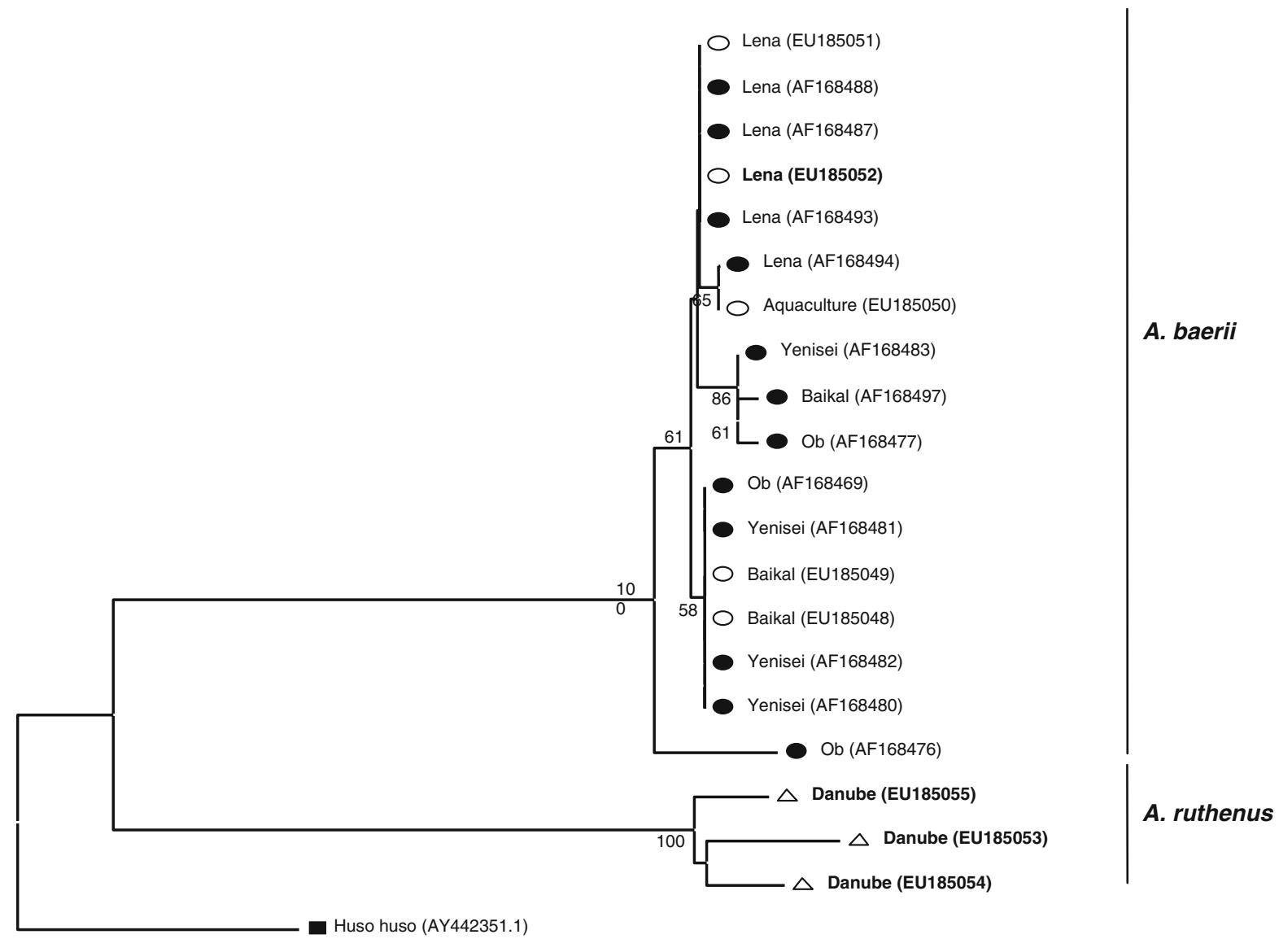

Fig. 3 Neighbour joining tree based on Kimura-2-parameter distances (for A. baerii (ellipses) and A. ruthenus (triangles), with the outgroup Huso huso (squares) including reference samples from different river systems. Mitochondrial haplotypes

jurisdiction along the length of the river. With improved water quality and stocking programs sterlet populations have recovered in the Slovak-Hungarian middle part of the Danube over the last few decades (Holčík et al. 2006), although catches in the Hungarian section are decreasing and have become unstable since the second half of the 1990s (Guti 2006). In the Lower Danube (River) below the Iron Gate (Djerdap) dams (rkm 1040 and rkm 934) sterlets are still present and reproducing (Paraschiv et al. 2006), although some researchers suspect that overharvesting and other factors are having a negative impact on populations (Bacalbasa-Dobrovici 1991; Lenhardt et al. 2006). In the Upper Danube River above Bratislava (rkm 1870), sterlet populations can be observed within the Upper Danube samples are indicated by solid black symbols. GenBank accession numbers follow the sample origin (river name/aquaculture)

traced back to the Middle Ages by means of historic written sources (Kinzelbach 1994; Zauner 1997). Nowadays the occurrence of this species depends heavily on stocking. Numerous efforts have been made to reintroduce this species into the free flowing stretches of the Danube, as well as impoundments in Germany and Austria starting in the 1970s. So far, however, there is no evidence for any successful establishment of a self-sustaining population by stocking. The Bavarian Fisheries Association (Landesfischereiverband Bayern e.V.) launched a conservation programme for the highly threatened population of sterlets on the Austrian-German border in 2005. Sterlets are documented regularly below the weir at Jochenstein since the 1950s in incidental 
catches (Zauner 1997). There is no evidence of stocking measures for these fish (Zauner 1997; Zauner 2007, pers. communication).

In contrast to the decline of natural sterlet populations, Siberian sturgeons and their hybrids have become very frequent in European aquaculture (Williot et al. 1993; Bronzi et al. 1999). The increasing catches of these species in European rivers correlates strongly with their increasing number represented in hatcheries. For example, Siberian sturgeons were reported for the Slovak-Hungarian stretch of the Danube River very recently (Holčík et al. 2006; Masár et al. 2006). Besides numerous reports for the unintentional escape of this species during recent decades, they were also deliberately released into tributaries of the Baltic Sea and Lake Ladoga with the aim of establishing self-sustainable populations (Kairov 1975). Several million fishes and fertilized eggs were released in Baltic waters (Debus 1998). Some of them were caught along the Swedish and Estonian coasts (Otterlind 1970; Paaver 1999); others were caught in Polish and German rivers (Gessner et al. 1999; Arndt et al. 2002). Although they are freshwater fishes, they also survived in the Baltic Sea due to low salinities in the prevailing brackish waters. Nevertheless the foundation of a self-sustaining population failed however.

Additionally, specimens from garden ponds and aquariums were often released into "freedom" after they extended a certain size. Moreover, they escape occasionally from aquaculture facilities in floodplains during flood events. Although these incidents have been expected to introduce competitive effects, an imminent danger for native populations by the introduction of allochthonous genotypes has so far not been considered, because until now no reproduction was reported for exotic sturgeons in European rivers. However, we have now documented the first observed case of natural reproduction of exotic Siberian sturgeons in the Danube River, and moreover, their hybridization with sterlets from one of the last remaining populations of the Upper Danube River. The origin of Siberian sturgeons and the timing of invasion into this section of the river are still unknown, and releases of this species into the area and neighboring river stretches have not been documented. Importantly, the Siberian sturgeon differs in one major characteristic from other sturgeons used in European aquaculture, in that it is potamodromous i.e. a freshwater species without an obligatory marine phase during its life-cycle. The Siberian sturgeon shares this trait with sterlets. Additionally, the reproduction observed in this case may be supported by the hydrological conditions of this river region.

Normally, both species differ in their autecology which should prevent hybridizations. Siberian sturgeons spawn at temperatures ranging between 8 and $21^{\circ} \mathrm{C}$ depending on the geographic location of the river, with spawning temperatures becoming more favorable from east to west (Ruban 2005). For sterlets, optimal spawning temperatures are between 12 and $17^{\circ} \mathrm{C}$; below $9^{\circ} \mathrm{C}$ and above $21^{\circ} \mathrm{C}$ spawning ceases (Sokolov and Vasil'ev 1989). Embryonic development of Siberian sturgeon is possible over a wide range of temperatures depending on its adaptation to both artic rivers in Siberia and warmer southern waters in Kazakhstan (Ruban 2005). The optimal temperature for embryonic development ranges between 11.4 and $14.9^{\circ} \mathrm{C}$, whereas Black Sea sturgeons prefer temperatures between 15 and $24^{\circ} \mathrm{C}$ (A. gueldenstaedtii, A. stellatus, A. ruthenus, $H$. huso). The lower temperature threshold of embryonic development for Siberian sturgeon is $4^{\circ} \mathrm{C}$, lower than for all other sturgeons $\left(\geq 12^{\circ} \mathrm{C}\right.$ - data reviewed in Ruban 2005). In addition, northern rivers are often affected by rapid temperature shifts during summer times. Siberian sturgeons therefore display adaptations to a wide range of temperatures, which may support their successful reproduction in the Danube River. However, the differences in spawning temperatures and embryonic development between the two species in question should result in different spawning times and grounds (spawning grounds are also affected by water levels). In this case, spawning migration of sterlets is interrupted by the Jochenstein weir, which causes their concentration below the dam. Additionally, water temperatures are decreased a short distance above Jochenstein at the confluence of the large alpine Inn River and the Danube River near Passau (rkm 2225), which may support reproduction and embryonic development of Siberian sturgeons in this area.

Considering these findings, the following management strategies are recommended: (i) Pushing back Siberian sturgeons in the Danube River; (ii) Supplemental breeding to boost the sterlet population and support the process of 'genetic cleaning'. Vergeer 
et al. (2004) demonstrated that introduction or genetic reinforcement is best achieved through material from the local population or, when unavailable, from several large populations. Although all sterlet populations are at historic low levels, genetic data indicate that historically, Danube sterlets formed a meta-population (Lippold, Reinartz \& Ludwig unpublished data) which is fragmented into isolated sub-populations by dams today. Finally, although our findings have negative implications for the conservation of most wild sturgeon stocks, they also provide valuable insight for future management measures in this section of the Danube, in documenting the existence of suitable spawning and nursery habitats for sturgeons, and the spawning of ripe sterlets in the region.

Acknowledgements The authors would like to thank the Landesfischereiverband Bayern e.V. (S. Hanfland) for funding which made the current findings possible. We would also like to thank G. Zauner (Engelhartszell, Austria) for his hospitality and for granting access to acipenserid fishes and tissue samples. We thank Jenny Giles (University of Queensland, Australia) for valuable comments.

\section{References}

Arndt GM, Gessner J, Raymakers C (2002) Trends in farming, trade and occurrence of native and exotic sturgeons in natural habitats in Central and Western Europe. J Appl Ichthyol 18:444-449. doi:10.1046/j.1439-0426.2002. 00415.x

Bacalbasa-Dobrovici N (1991) Die Rettung der Donauwanderstöre. Fischer Teichwirt 6:206-207

Becker LA, Pascual MA, Basso NG (2007) Colonization of the Southern Patagonia Ocean by exotic Chinook salmon. Conserv Biol 21:1347-1352. doi:10.1111/j.1523-1739. 2007.00761.x

Birstein VJ, Poletaev AI, Goncharov BF (1993) DNA content in Eurasian sturgeon species determined by flow cytometry. Cytometry 14:377-383. doi:10.1002/cyto.990140406

Birstein VJ, Betts J, DeSalle R (1998) Molecular identification of Acipenser sturio specimens: a warning note for recovery plans. Biol Conserv 84:97-101. doi:10.1016/ S0006-3207(97) 00091-8

Birstein VJ, Ruban G, Ludwig A, Doukakis P, DeSalle R (2005) The enigmatic Caspian Sea Russian sturgeon: how many cryptic forms does it contain? System Biodivers 3:203-218

Bronzi P, Rosenthal H, Arlati G, Williot P (1999) A brief overview on the status and prospects of sturgeon farming in Western and Central Europe. J Appl Ichthyol 15:224227. doi:10.1111/j.1439-0426.1999.tb00239.x

Debus L (1995) Zur Systematik der Störe. Fischer Teichwirt $8: 281-285$
Debus L (1998) Experiments to stock the Baltic with Acipenseridae-a chronicle of trial and error. Proceedings of Polish-German Symposium-Swinoujscie, 19-20th November 1996. Sea Fisheries Institute Danzig, pp 120132

Gessner J, Debus L, Filipiak J, Spratte S, Skora SK, Arndt GM (1999) Catches of sturgeons in German and adjacent waters since 1980. J Appl Ichthyol 15:136-142. doi: 10.1111/j.1439-0426.1999.tb00223.x

Freyhof J, Lieckfeldt D, Pitra C, Ludwig A (2005) Molecules and morphology: evidence for introgression of mitochondrial DNA in Dalmatian cyprinids. Mol Phylogenet Evol 37:347-354. doi:10.1016/j.ympev.2005.07.018

Guti G (2006) Past and present status of sturgeons in Hungary. Proceedings of the 36th International Conference of IAD. Austrian Committee Danube Research/IAD, Vienna, pp 143-147

Holčík J, Klindová A, Masár J, Mészáros J (2006) turgeons in the Slovakian rivers of the Danube River basin: an overview of their current status and proposal for their conservation and restoration. J Appl Ichthyol 22(Suppl 1):7-22

Hughes J, Goudkamp K, Hurwood D, Hancock M, Bunn S (2003) Translocation causes extinction of a local population of the freshwater shrimp Paratya australiensis. Conserv Biol 17:1007-1012. doi:10.1046/j.1523-1739. 2003.01636.x

Kairov EA (1975) Experiments on the introduction of sturgeons in the Riga Gulf. Rybnoe Khozyaistvo 1975(6):1011 In Russian

King TL, Lubinski BA, Spidle AP (2001) Microsatellite DNA variation in Atlantic sturgeon (Acipenser oxyrinchus oxyrinchus) and cross-species amplification in the Acipenseridae. Conserv Genet 2:103-119. doi:10.1023/A: 1011895429669

Kinzelbach R (1994) Ein weiterer alter Nachweis des Sterlets, Acipenser ruthenus, der württembergischen Donau. In: Kinzelbach R (ed) Biologie der Donau, Limnologie aktuell 2. Gustav Fischer Verlag Stuttgart, Jena

Lenhardt M, Jaric I, Bojovic D, Cvijanovic G, Gacic Z (2006) Past and current status of sturgeon in the Serbian part of the Danube River. Proceedings 36th International Conference of IAD. Austrian Committee Danube Research/ IAD, Vienna, pp 148-151

Ludwig A (2006) A sturgeon view on conservation genetics. Eur J Wildl Res 52:3-8. doi:10.1007/s10344-005-0006-2

Ludwig A (2008) Identification of Acipenseriformes species in trade. J Appl Ichthyol 24(S1):2-19

Ludwig A, Belfiore NM, Pitra C, Svirsky V, Jenneckens I (2001) Genome duplication events and functional reduction of ploidy levels in sturgeon (Acipenser, Huso and Scaphirhynchus). Genetics 158:1203-1215

Ludwig A, Debus L, Jenneckens I (2002) A molecular approach for trading control of black caviar. Int Rev Hydrobiology 87:661-674. doi:10.1002/1522-2632(200211)87:5/6 $\leq 661::$ AID-IROH661 $\geq 3.0 . C O ; 2-S$

Ludwig A, Congiu L, Pitra C, Fickel J, Gessner J, Fontana F, Patarnello T, Zane L (2003) Nonconcordant evolutionary history of maternal and paternal lineages in Adriatic sturgeon. Mol Ecol 12:3253-3264

Masár J, Turanský R, Krupka I, Kautman J (2006) The first record of the Siberian sturgeon (Acipenser baerii) in 
Slovak-Hungarian stretch of the Danube River. Acta Rer Nat Mus Nat Slov LII:50-55

Maury-Brachet R, Rochard E, Durrieu G, Boudou A (2008) The 'Storm of the Century' (December 1999) and the Accidental Escape of Siberian Sturgeons (Acipenser baerii) into the Gironde Estuary (Southwest France). Environ Sci Pollut Res 15: in press (doi: http://dx.doi. org/10.1065/espr2007.12.469).

May B, Krueger CC, Kincaid HL (1997) Genetic variation at microsatellite loci in sturgeon: primer sequence homology in Acipenser and Scaphirhynchus. Can J Fish Aquat Sci 54:1542-1547. doi:10.1139/cjfas-54-7-1542

McQuown EC, Sloss BL, Sheehan RJ, Rodzen J, Tranah GJ, May B (2000) Microsatellite analysis of genetic variation in sturgeon: New primer sequences for Scaphirhynchus and Acipenser. Trans N Am Fish Soc 129:1380-1388. doi:10.1577/15488659(2000) 129 $\leq 1380: M A O G V I \geq 2.0 . C O ; 2$

Otterlind G (1970) Swedish records of sturgeons (Acipenser gueldenstaedtii and Acipenser baerii) introduced into the Baltic by the USSR. ICES C.M. 1970(E):1-13

Paaver T (1999) Historic and recent records of native and exotic sturgeon species in Estonia. J Appl Ichthyology 15:129-132. doi:10.1111/j.1439-0426.1999.tb00221.x

Paraschiv M, Suciu R, Suciu M (2006) Present state of sturgeon stocks in the Lower Danube River, Romania. Proceedings of the 36th International Conference of IAD. Austrian Committee Danube Research/IAD, Vienna, pp 152-158

Pavlov DS (1989) Structures assisting the migrating of nonsalmonid fish USSR. FAO Fisheries Techn. Papers 308, $98 \mathrm{pp}$
Pikitch EK, Doukakis P, Lauck L, Chakrabarty P, Erickson DL (2005) Status, trends and management of sturgeon and paddlefish fisheries. Fish Fish 6:233-265. doi:10.1111/j. 1467-2979.2005.00190.x

Reinartz R (2002) Sturgeons in the Danube River; biology, status, conservation. Literature and information study on behalf of the International Association for Danube Research (IAD), Landesfischereiverband Bayern e.V. and Bezirk Oberpfalz, $150 \mathrm{pp}$

Ruban GI (2005) The Siberian sturgeon Acipenser baerii Brandt-Species structure and ecology. World Sturgeon Conservation Society, Special Publication No. 1, Books on Demand GmbH, Norderstedt, Germany.

Sokolov LI, Vasil'ev VP (1989) Acipenser ruthenus Linnaeus, 1758. In Holčík J (ed) The freshwater fishes of Europe. General introduction to fishes-Acipenseriformes, vol 1/ II. Aula-Verlag, Wiesbaden, pp 226-262

Vergeer P, Sonderen E, Oubourg NJ (2004) Introduction strategies put to the test: local adaptation versus heterosis. Conserv Biol 18:812-821. doi:10.1111/j.15231739.2004.00562.x

Williot P, Bronzi P, Arlati G (1993) A very brief survey of status and prospects of freshwater sturgeon farming in Europe (EEC). In Kestemont P, Billard R (eds) Workshop in aquaculture of freshwater species-European Aquaculture Society Special Publication 20, pp 32-36

Wolf DE, Takebeayashi N, Rieseberg LH (2001) Predicting the risk of extinction through hybridization. Conserv Biol 15:10391053. doi:10.1046/j.1523-1739.2001.0150041039.x

Zauner G (1997) Acipenseriden in Österreich. Österreichs Fischerei 50:183-187 